\title{
PRODUK PEMBIAYAAN PINJAM SAMBIL SIMPAN UANG (PISANG) BPRS BAHARI BERKESAN KOTA TERNATE: UPAYA PENINGKATAN EKONOMI UMMAT
}

\author{
Risdan Harly \\ Institut Agama Islam Negeri (IAIN) Ternate \\ Syaifuddin \\ Institut Agama Islam Negeri (IAIN) Ternate
}

\begin{abstract}
ABSTRAK
Tujuan dari penelitian untuk mengetahui dan menganalisa, bagaimanakah penerapan akad mudharabah dalam pembiayaan Pinjam Sambil Simpan Uang (PISANG) pada PT PBRS Bahari Berkesan Kota Ternate, untuk mengetahui dan menganalisa, bagaimanakah Peran Produk Pinjam Sambil Simpan Uang (PISANG) terhadap pemberdayaan upaya peningkatan ekonomi ummat. Metode Penelitian yang digunakan adalah jenis penelitian kualitatif deskriptif. Hasil penelitian menunjukan penerapan akad mudharabah dengan pembiayaan produk Pinjam Sambil Simpan Uang (Pisang) oleh Bank BPRS Bahari Berkesan di Kota Ternate, berjalan maksimal karena banyak masyarakat telah sukses untuk meningkatkan ekonomi mereka baik berjangka pendek, menengah dan jangka panjang, serta bank mampu memberikan pemahaman sistem ekonomi Islam dalam menggunakan akad Mudharabah dengan sistem bagi hasil antara bank dan nasabah.
\end{abstract}

Kata Kunci: Akad Mudharabah, Produk Pembiayaan PISANG, Ekonomi Ummat

\section{ABSTRACT}

The purpose of the research is to find out and analyze, how the application of mudharabah agreements in the financing of Borrow While Saving Money (PISANG) at PT. PBRS Bahari Berkesan Kota Ternate, to find out and analyze, how the Role of Borrowing Products While Saving Money (PISANG) to empower efforts to improve the economy of the ummah. The research method used is a type of descriptive qualitative research. The results of the study showed the implementation of mudharabah agreements with the financing of Loan While Saving Money (PISANG) products by Bank BPRS Bahari Berkesan in Ternate City, running optimally because, many communities have been successful to improve their economies both short, medium and long term and banks are able to provide an understanding of the Islamic economic system in using Mudharabah agreements with profit sharing systems between banks and customers.

Keywords: Akad Mudharabah, PISANG Financing Products, Ummah Economy 


\section{A. Pendahuluan}

Perkembangan ekonomi Islam di Indonesia saat ini semakin pesat dan sangat identik dengan berkembangnya lembaga keuangan syariah. Kehadiran perbankan syari'ah di Ternate menampakkan pertumbuhan yang pesat. Dalam waktu 10 tahun terakhir sudah hadir 3 bank umum syariah dan 1 Bank Pembiayaan Rakyat Syari'ah milik Pemda Kota Ternate yaitu PT. BPRS. Bahari Berkesan.

Kehadiran Lembaga Perbankan Syariah di Ternate telah memberikan sebuah alternatif, bank (lembaga keuangan) syariah telah memformulasikan sistem interaksi kerja yang dapat menghindari aspek-aspek negatif dari sistem kerja bank konvensional, yaitu dengan menerapkan beberapa sistem, di mana harus diciptakan bank (lembaga keuangan) syariah yang tidak bekerja atas dasar bunga melainkan atas sistem bagi hasil, antara lain yang dikenal dalam fiqh mu'amalah sebagai transaksi mudharabah atau qiradh. ${ }^{1}$

Dalam operasional Bank Pembiayaan Rakyat Syariah, mudharabah merupakan salah satu bentuk akad pembiayaan yang akan diberikan kepada nasabahnya. Sistem dari mudharabah ini merupakan akad kerja sama usaha antara dua pihak di mana pihak pertama menyediakan seluruh modal, sedangkan pihak lainnya menjadi pengelola.

Bank Pembiayaan Rakyat Syariah (BPRS) Bahari Berkesan Ternate, Maluku Utara (Malut), yang merupakan salah satu Bank Syariah milik Pemerintah Daerah Kota Ternate hadir dalam memberikan terobosan tersendiri terhadap pengembangan ekonomi Islam di Ternate khususnya dan Maluku Utara umumnya melalui pelayanan Jasa Perbankan. Tujuan pendirian BPRS Bahari Berkesan ini diharapkan oleh Pemerintah Daerah dapat memberi manfaat kepada masyarakat terutama pengusaha kecil dalam pengembangan usaha juga peningkatan taraf hidupnya dari profitnya diharapkan BPRS Bahari Berkesan dapat memberikan kontribusi Pendapatan Asli Daerah (PAD) pada Kota Ternate. Untuk itu dalam

\footnotetext{
${ }^{1}$ Muhammad, Konstruksi Mudharabah Dalam Bisnis Syari'ah (Yogyakarta: BPFE, 2005).
} 
pelaksanaan operasional memberi kemudahan kepada masyarakat dengan melihat atas kebutuhan Masyarakat, terutama pelaku usaha kecil dan menengah (UKM) dalam memperoleh pinjaman untuk pengembangan usaha di Ternate. keberadaan BPRS Bahari Berkesan itu untuk memberikan akses kepada pengusaha menengah ke bawah mendapatkan pinjaman dengan syarat mudah dan ringan. Maka BPRS Bahari Berkesan mengeluarkan produk pembiayaan dengan nama Pinjam Sambil Simpan Uang (PISANG) dengan tetap mengedepankan prinsip kehati-hatian, sehingga dana yang tersalurkan tersebut tetap berstatus lancar dan dapat dikembalikan dengan baik. Sesuai dengan permintaan Pemerintah Kota Ternate dalam hal pelayanan kepada masyarakat kalangan bawah dan tetap mengutamakan pertumbuhan dan menjaga kesehatan bank dalam upaya memajukan BPRS Bahari Berkesan.2 Pertanyaan yang perlu dijawab adalah bagaimana skema mudharabah atau bagi hasil dalam pembiayaan Pinjam Sambil Simpan Uang (PISANG) di PT PBRS Bahari Berkesan Kota Ternate? Selanjutnya bagaimana peran produk pinjam sambil simpan uang (PISANG) pada pemberdayaan upaya peningkatan ekonomi ummat?. Untuk itu diperlukan akad Pembiyaan Mudharabah (Qiradh) adalah akad kerja sama suatu usaha antara dua pihak di mana pihak pertama (malk, sahib al-mal,) menyediakan seluruh modal, sedangkan pihak kedua ('amil, mudharib, nasabah) bertindak selaku pengelola, dan keuntungan usaha dibagi di antara mereka sesuai kesepakatan yang dituangkan dalam kontrak. ${ }^{3}$ Menggunakan jenis penelitian kualitatif dengan metode wawancara yang mendalam diharapkan mampu menemukan jawaban penting terhadap produk PISANG kedepan.

\section{B. Sejarah Berdirinya (PT) Bank Pembiayaan Rakyat Syari'ah (BPRS) Bahari Berkesan Kota Ternate}

Perseroan Terbatas (PT) Bank Pembiayaan Rakyat Syari'ah (BPRS) Bahari Berkesan kota Ternate didirikan pada tanggal 19 April 2012 berdasarkan izin usaha Keputusan Gubernur Bank Indonesia No. 14/17/KEP.GBI/DpG/2012. PT. Bank

2 Hi. Burhan Abdurrahman, Wali Kota Ternate, Pemilik Saham Bank BPRS Kota Ternate, Wawancara, Ternate di Kediaman, tanggal 23 Juni 2018

${ }^{3}$ Dr. Basaria Nainggolan, Perbankan Syariah Di Indonesia (Depok: PT Rajagrafindo Persada, 2016). 
Pembiayaan Rakyat Syari'ah (BPRS) Bahari Berkesan adalah perusahaan milik pemerintah kota Ternate. ${ }^{4}$

Bank BPRS Bahari Berkesan Kota Ternate adalah salah satu bank yang lahir dari pemerintah kota Ternate, dengan melihat peluang dari pengelolaan perputaran uang di Kota Ternate, dengan tujuan dalam menunjang pembangunan kota Ternate, Selain itu pemerintah untuk mempermudahkan masyarakat Kota Tenate dalam membangun usaha demi mewujudakan kebutuhan ekonomi. Oleh karena itu Pemerintah Kota Ternate memberikan modal untuk kemajuan Bank BPRS Kota Ternate, pemberian modal ini sesuai dari hasil wawancara peneliti kepada bapak Alwi Albaar, Komisaris Bank BPRS Bahari Berkesan Kota Ternate sebagai berikut:

Kepemilikan Bank Pembiayaan Rakyat Syari'ah (BPRS) Bahari Berkesan adalah milik pemerintah kota Ternate, dimana komposisi modalnya adalah 99,50\% dimiliki oleh pemerintah kota Ternate dan 0,50\% dimiliki oleh Ir. Arifin Djafar dengan modal disetor Rp. 3.010.000.000,- (Tiga Milyar Sepuluh Juta Rupiah). ${ }^{5}$

Menjadi Bank Pembiayaan Rakyat Syari'ah yang menguntungkan, berkembang dan memberikan kesejahteraan bagi masyarakat. Adapun Misi Bank Pembiayaan Rakyat Syari'ah (BPRS) Bahari Berkesan adalah menjalankan usaha dalam bidang keuangan dan perbankan berdasarkan prinsip-prinsip syari'ah. Oleh karena itu tujuan Bank Pembiayaan Rakyat Syari'ah (BPRS) Bahari Berkesan adalah membantu dan mendorong pertumbuhan ekonomi dan pembangunan daerah di segala bidang dalam rangka meningkatkan taraf hidup masyarakat Ternate. ${ }^{6}$

Bank Pembiayaan Rakyat Syari'ah (BPRS) Bahari Berkesan merupakan institusi keuangan yang berskala lokal dengan orientasi kegiatan bisnis yang lebih diarahkan kepada usaha berskala mikro, kecil dan menengah pada berbagai sektor. Sesuai misi pendirian, sasaran utama kegiatan BPRS berupa penghimpunan dan penyaluran dana atau pembiayaan kepada masyarakat di sekitar lokasi usaha BPRS baik

${ }^{4}$ Data Dokumen Laporan Ahir Tahun, PT.BPRS Bahari Berkesan, 2018

${ }^{5}$ Alwi Albar, Komisaris Bank BPRS Bahari Berkesan Kota Ternate, (Wawancara, 20 Agustus 2018, Pkl 10.12:10. 45. Wit)

6 Data Dokumen Laporan Bank BPRS Bahari Berkesan Kota Ternate Tahun 2018 
kalangan muslim maupun non muslim, masyarakat golongan ekonomi lemah, pengusaha menengah dan kecil, tokoh, masyarakat dan nasabah potensial lainnya.

Kegiatan usaha diarahkan kepada industri kecil menengah dan industri kerajinan rumah tangga (home industri). Secara sektoral usaha juga diperuntukkan bagi pedagang, nelayan, pekebun, jasa berskala mikro kecil dan menengah yang tersebar di wilayah Ternate. ${ }^{7}$

Sesuai dengan Undang-Undang Perbankan Syari'ah Nomor 21 tahun 2008 bahwa tugas pokok dari bank adalah menerima simpanan dari masyarakat dalam bentuk tabungan dan deposito dan menyalurkan kembali kepada masyarakat dalam bentuk pembiayaan, sehubungan dengan tugas pertama yaitu menerima simpanan dari masyarakat, hingga Desember 2012 BPRS mampu menggalang dana masyarakat sebesar Rp. 7.089.359.672,- Sedangkan tugas pokok kedua penyaluran pembiayaan kepada masyarakat saldo pembiayaan yang diberikan hingga akhir Desember 2012 mencapai Rp. 7.093.101.500,-8

Untuk kegiatan operasional dan akunting PT. BPRS Bahari Berkesan menggunakan software House of Interprise Aplication dari Heasof Bank. Sebagai pelapor Sistem Informasi Debitur (SID) software dari pusat informasi kredit Bank Indonesia.

\section{Penerapan Akad Mudharabah dalam Pembiayaan Pinjam Sambil Simpan Uang (PISANG) pada PT. PBRS Bahari Berkesan Kota Ternate}

Perkara pinjam meminjam ini termasuk dalam perbuatan tolong menolong antar sesama manusia sehingga ummat Islam boleh melakukannya asal memenuhi kriteria dan adab pinjam meminjam dengan benar. Tanpa memenuhi ketentuan dan rukun yang berlaku maka pinjam meminjam bisa dikatakan tidak sah. Memberikan pinjaman kepada orang lain tentunya tidak hanya memberi manfaat kepada orang yang dipinjamkan melainkan juga mendatangkan pahala bagi mereka yang memberikan pinjaman atau mereka yang memberikan sedekah. Siapapun ummat

\footnotetext{
7 Data Dokumen Laporan Ahir Tahun PT. BPRS Bahari Berkesan 2018

8 Data Dokumen Laporan BPRS Bahari Berkesan Kota Ternate 2018.
} 
muslim yang memberikan pinjaman yang sifatnya baik dan menolong orang lain maka ia juga akan mendapatkan hal yang sama yakni dihilangkan kesukarannya. Sebagaimana disampaikan oleh Dirut Utama Operasional Bank BPRS Bahari Berkesan Kota Ternate, yakni Ibu Rita Yasin, pada saat peneliti melakukan wawancara sebagai berikut:

Bank BPRS Baharai Berkesan Kota Ternate adalah sebagai seorang muslim hendaknya saling tolong menolong dalam kebaikan dan menghilangkan kesukaran orang lain misalnya dengan memberikan pinjaman saat orang lain membutuhkannya. Dengan kata lain, pinjaman hukumnya diperbolehkan dalam islam jika memenuhi rukun dan ketentuan barang pinjaman serta peminjam mengembalikan harta atau benda yang dipinjamnya tesebut dalam jangka waktu yang sudah ditentukan atau sesuai dengan kebaikan hati orang yang meminjamkan apabila ia memberikan waktu yang selonggar-longgarnya pada peminjam. ${ }^{9}$

Berdasarkan prinsip mudharabah bank syariah harus melakukan pengawasan yang ketat terhadap penggunaan dana tersebut, sehingga langkah-langkah dalam proses penyaluran pembiayaan mudharabah ini sesuai dengan karakter dan standart dalam penyaluran dana.

Dalam Prinsip Akad Mudharabah Menurut Saffi Antoni bahwa Pembiayaan Mudharabah ini bersifat produktif karena diinvestasikan untuk penyediaan modal kerja sehingga dapat memberdayakan perekonomian masyarakat kecil melalui Usaha Mikro, Kecil, dan Menengah (UMKM). Pemberdayaan usaha kecil merupakan salah satu cara untuk membuka lapangan kerja baru yang dapat meningkatkan pendapatan masyarakat dan mengurangi tingkat pengangguran atau kemiskinan. Pembiayaan mudharabah dengan prinsip bagi hasil dapat memberikan dampak yang positif terhadap perkembangan sektor riil, khususnya usaha mikro, kecil dan menengah yang menjadi indikator kemajuan roda perekonomian negara melalui kegiatan investasi. ${ }^{10}$

9 Rita Yasin, Direktur Utama Operasional Bank BPRS Bahari Berkesan Kota Ternate, Wawancara, Ternate tanggal 23 Agustus 2018

${ }^{10}$ Muhammad Syafi'i Antonio, Bank Syriah Wacana Ulama Dan Cendekiawan (Jakarta: Tazkia Institute, 2002). 
Sebelum memberikan pembiayaan pihak bank syariah melakukan penilaian terlebih dahulu terhadap calon mudharib atau nasabah/mudharib yang mengajukan permohonan pembiayaan. Hal ini dilakukan agar pembiayaan yang diberikan selalu memperhatikan dan mempertimbangkan hal-hal sebagai keamanan pembiayaan (safety) yaitu harus benar diyakini bahwa pembiayaan tersebut dapat dilunasi kembali, Terarahnya tujuan pembiayaan, yaitu bahwa pembiayaan akan digunakan untuk tujuan yang sejalan dengan kepentingan masyarakat atau sekurang-kurangnya tidak bertentangan dengan peraturan yang berlaku dan menguntungkan, baik untuk bank sendiri maupun kepada mudahrib atau nasabah/mudharib dengan semakin berkembangnya usaha mereka. ${ }^{11}$

Awal dari proses pemberian pembiayaan pada bank adalah ketika para calon nasabah/mudharib telah mengajukan terlebih dahulu permohonan pembiayaan kepada bank syariah. Pada prinsipnya permohonan pembiayaan ini berfungsi sebagai bukti adanya permohonan dari perorangan atau badan usaha kepada bank dengan catatan bahwa permohonan tersebut menyertakan lampiran-lampiran sebagai informasi dalam evaluasi dari pemberian pembiayaan. Langkah-langkah yang di ambil oleh bank syariah dalam pembiayaan pada saat calon nasabah/mudharib menyampaikan atau mengajukan usul permohonan pinjamannya, dari Tahap Permohonan Pembiayaan, Tahap Penelitian Berkas Investigasi Pembiayaan dan Analisis Pembiayaan.

Dengan demikian, implementasi ekonomi Islam dengan akad Mudharabah menjadi urgen di tengah masyarakat, mengingat karakter jenis usaha dan pola kegiatan transaksionalnya yang pro rakyat bawah, menggerakkan dinamika ekonomi mikro dalam wujud kemitraan usaha kecil menengah, lebih berkeadilan sosial karena tanpa bunga yang membelit dan mengandung nilai sakral religius bagi komunitas masyarakat muslim yang mayoritas di negeri ini.

Setelah pihak bank dan nasabah/mudharib telah menemui kata sepakat dalam hal pemberian pembiayaan oleh bank kepada nasabah/mudharib maka

${ }^{11}$ Ascaraya, Akad Dan Produk Bank Syariah. (Jakarta: Raja Grafindo Persada, 2008). 
kesepakatan yang terjadi pada para pihak tersebut akan dituangkan dalam suatu perjanjian pembiayaan. Dalam arti perjanjian pembiayaan tersebut adalah suatu perbuatan hukum antara pihak bank di satu pihak dengan nasabah/mudharib di pihak lain, yang mana isi perjanjian tersebut dituangkan dalam bentuk tertulis agar memudahkan pembuktian bila terjadi wanprestasi dikemudian hari. Berdasarkan ketentuan Pasal 1 angka (11) Undang-Undang No.10 Tahun 1998, perjanjian pembiayaan atau persetujuan akad pembiayaan dibuat secara kontraktual berdasarkan pinjam-meminjam yang diatur dalam buku III bab 13 Kitab UndangUndang Hukum Perdata. Oleh karena itu ketentuan mengenai berakhirnya perikatan, dalam hal ini Pasal 1381 KUH Perdata berlaku juga dalam Perjanjian pembiayaan ini, kecuali ditentukan lain oleh para pihak yang dituangkan dalam akad. Sebagaimana yang telah disebutkan di atas bahwa pembiayaan mudharabah ini sangat rentan dan berpotensi terhadap Moral Hazard dari pelaku usaha atau mudharib, untuk itu pihak bank syariah perlu mengadakan pengawasan. Dan setiap bank syariah tentu menginginkan keuntungan yang tinggi, karena beroperasi dan berhasilnya suatu bank dapat dilihat melalui keuntungan yang diperoleh. Akan tetapi tingkat keuntungan bersih yang dihasilkan tidak terlepas dari pengaruh dan faktor-faktor yang dapat dikendalikan dan faktor-kaktor yang tidak dapat dikendalikan oleh pihak bank syariah itu sendiri. Berdasarkan dengan keterangan dari Ibu Rita Yasin selaku Direktur pada saat diwawancara menjelaskan yaitu:

Perjanjian mudharabah merupakan salah satu produk bagi hasil yang dilaksanakan oleh BPRS Bahari Berkesan Ternate, dengan berdasarkan prinsip syariah. Pada umumnya. Bank lebih menekankan kepada pembiayaan mudharabah terhadap usaha Koperasi Pegawai Negeri, pertanian, pertambangan, industri, listrik, Gas dan Air, konstruksi atau proyek, perdagangan, transportasi dan komunikasi, jasa dunia usaha, usaha jasa sosial, namun tetap tidak mengesampingkan pembiayaan terhadap usaha-usaha yang lain sepanjang tidak bertentangan dengan syari' at Islam. ${ }^{12}$

Berdasarkan hasil wawancara tentang penggunakaan akad mudharabah dengan produk Pinjam Sambil Sinpan Uang (PISANG), dengan pendekatan hukum ekonomi

12 Rita Yasin, Direktur Utama Operasional Bank BPRS Bahari Berkesan Kota Ternate, Wawancara, Ternate tanggal 13 Mei 2018. 
Islam secara filosofis mempunyai prinsip akad mudharabah menjadi jembatan relasi kemanusiaan bidang kerja sama ekonomi atas dasar cinta dan kasih sayang antara para pihak yang terlibat dalam perjanjian, bukan saling memanfaatkan antara satu pihak terhadap pihak yang lain. Akad mudharabah akan terjalin manakala kebutuhan para pihak bertemu dalam satu kesepakatan untuk kerjasama ekonomi. Jika ada seseorang mempunyai kelebihan harta dan dia melihat orang lain mempunyai kemampuan untuk mengembangkan, maka pemilik modal dapat melakukan kerjasama dengan orang yang profesional dalam menjalankan usaha untuk kerjasama atas dasar saling menguntungkan. Bagi pemilik modal, dia akan memperoleh keuntungan, pertama pahala dari Allah karena telah memberi ruang bagi orang lain untuk berkembang secara ekonomis dan mengangkat kemiskinan dan masalah ekonomi.

Bank pada prakteknya menerapkan prinsip pembiayaan mudharabah Muthlaqah dengan memberikan fasilitas dan otoritas serta hak sepenuhnya kepada nasabah/mudharib untuk melakukan usaha dan mengelola dana yang diperoleh dari pembiayaan mudharabah ini sesuai dengan yang diinginkannya dan hal tersebut akan disebutkan dalam perjanjian atau akad/kontrak yang disepakati oleh kedua belah pihak. Untuk pembiayaan mudharabah muthlaqah ini pihak BPRS Bahari Berkesan Ternate membaginya kepada dua kelompok mudharib, yaitu mudharib perorangan dan mudharib badan usaha.

\section{Peran Produk Pinjam Sambil Simpan Uang (PISANG) Terhadap Upaya Peningkatan Ekonomi Ummat}

Sistem Pinjaman produk (PISANG) Pinjam Sambil Simpan modal adalah yang diberikan oleh suatu bank BPRS kepada masyarakat untuk mengengembangkan usaha pedagang di pasar Higenis penyalur untuk membiayai kebutuhan pengusaha kecil kerja sehingga dapat berjalan lancar. Pinjaman diperlukan untuk membiayai keperluan-keperluan dana awal dalam pengembangan usaha awal yang dibangaun dalam satu siklus usaha, yaitu mulai dari pengeluaran uang tunai hingga penerimaan dam sambil menyimpang yang didapat dalam sistem jual beli yang dilakukannya dan hasilnya di bagi sama dan disimpang langsung oleh pihak Bank 
BPRS Bahari Berkesan uang yang dari pedagang tersebut untuk keperluankeperluan yang habis dalam satu siklus usaha diantaranya seperti pembelian bahan baku, atau biaya-biaya lain yang berkaitan dengan kebutuhan masyarakat seharihari yang melakukan peminjaman dikemudian hari dalam mewujudkan kebutuhan ekonomi yang akan datang.

Konsep pinjaman yang dilakukan oleh Bank BPRS Bahari Berkesan kepada pedagang merupakan salah satu produk baru yang di gagas oleh Bank BPRS Bahari Berkesan kota Ternate yaitu (PISANG) Pinjam sambil Simpan hal itu dilakukan untuk mengembangkan ekonomi ummat yang bergerak dalam dunia bisnis terutama kepada pedagang kecil yang berada dilingkungan pasar Higenis Gamalama. Lembaga keuangan bank maupun non bank memang diperlukan guna memberikan kesejahteraan masyarakat. Oleh karena itu, produk pinjam sambil simpan menjadi salah satu wadah baru yang terus disosialisasikan ke khalayak luas mengenai pinjaman modal kerja sangat dibutuhkan guna menekan tingkat keimiskinan dalam proses pemberian pinjaman modal kerja.

Beberapa potensi penting dari ekonomi Islam adalah bagaimana memobilisasikan sumber-sumber domestik dari hasil produk Pinjam Sambil Simpan untuk pertumbuhan ekonomi. Ada tiga aspek yang bisa dikemukakan di sini berkaitan dengan sumber-sumber domestic tersebut yaitu: Potensi menabung; Mobilisasi untuk menabung; Alokasi dan pemanfaatan tabungan untuk pertumbuhan ekonomi.

\section{Produk PISANG dalam Pemberdayaan Ekonomi Masyarakat kota Ternate}

Pengelola BPRS Bahari Berkesan menyadari bahwa banyak potensi yang belum dimaksimalkan di sekitar masyarakat kepulauan di kota Ternate. Banyak orang yang memiliki dana lebih hanya ditabung di bank bank konvensional atau bahkan disimpan di rumah. Dengan pendekatan pendekatan tertentu ke masyarakat serta melakukan berbagai kegiatan sosial dan pembinaan bisnis, maka dapat menarik minat para pemilik dana untuk menginvestasikan dananya ke BPRS Bahari 
Berkesan. Hal ini disampaikan oleh Ibu Rita Yasin Sebagai Direktur Operasional Bank BPRS Bahari Berkesan Kota Ternate sebagai berikut:

Sebenarnya yang membuat banyak orang kaya ingin menginvestasikan dana ke kita itu karena faktor kepercayaan, Mereka juga melihat kegiatan kegiatan sosial kita. Jadi itu daya tariknya. ${ }^{13}$

Penggalangan potensi masyarakat tidak terbatas pada dana orang-orang kaya saja, namun juga sumber daya tenaga manusia. Rita Yasin mengatakan bahwa sekarang sudah banyak pemuda yang memilih untuk memulai bisnis di sini (desa) ternyata penghasilannya cukup besar. Dari tahun 2017 hingga 2018, fungsi intermediasi ini terus berkembang ditandai dengan semakin banyaknya penabung dan investor baik dari sisi kualitas maupun kuantitas dan juga semakin banyaknya pengguna dana baik dari sisi kuantitas dan kualitas. Keadaan tabungan dan investasi beserta pembiayaan yang dikeluarkan oleh BPRS Bahari Berkesan terangkum sebagai berikut:

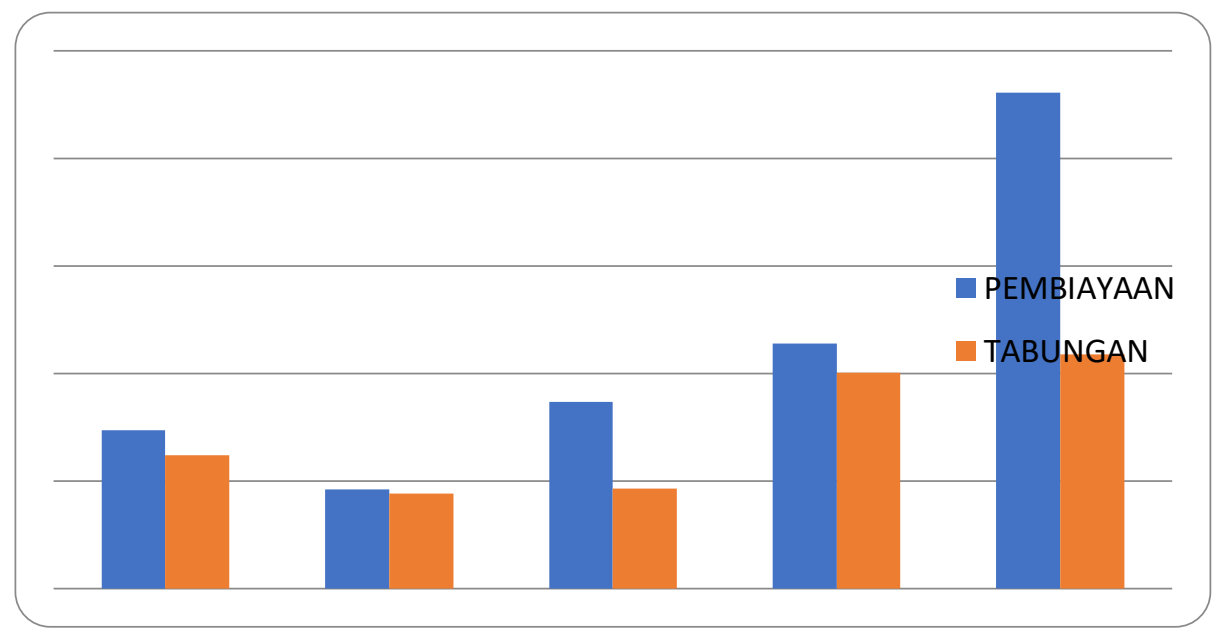

Gambar 3.4. Intermediasi Dana BPRS Bahari Berkesan 2012 s/d 2016

Semakin meningkatnya tabungan dan investasi serta jumlah pembiayaan mengindikasikan bahwa fungsi intermediasi ekonomi BPRS Bahari Berkesan sebagai perantara antara pemilik dana dan pengguna dana berjalan dengan baik. Selain potensi dana dan sumber daya tenaga manusia, terdapat potensi lain yang telah

13 Rita Yasin, Direktur Utama Operasional Bank BPRS Bahari Berkesan Kota Ternate, Wawancara, Ternate tanggal 23 November 2018 
digalang oleh BPRS Bahari Berkesan yaitu jaringan bisnis. Rita , beberapa jaringan bisnis yang saat ini telah berjalan dalam kegiatan para nasabah BPRS Bahari Berkesan adalah pembiayaan untuk budidaya rumput laut, usaha pengolahan ikan, dan jaringan penjualan ikan di pasar pasar seperti pasar induk Gamalama atau pasar higienis, pasar syariah Sasa, pasar Bastiong dan sebagainya. Sehingga menempatkan BPRS Bahari Berkesan sebagai lembaga intermediasi di masyarakat.

Fungsi intermediasi yang tidak bisa ditinggalkan oleh BPRS Bahari Berkesan adalah fungsi sosial karena merupakan salah satu core BPRS Bahari Berkesan dan juga menjadi jalan bagi kepercayaan para penabung dan para investor. Sebagaimana disampaikan oleh Komisaris Bank BPRS Bahari Berkesan Alwi Albaar, pada saat diwawancara sebagai berikut:

Hingga saat ini BPRS Bahari Berkesan terus menyalurkan dana-dana sosial untuk keperluan sosial dan untuk keperluan bisnis Berdasarkan data keuangan BPRS Bahari Berkesan, dana sosial ini dari tahun ke tahun terus bertambah. Pada akhir tahun 2014 dana sosial ini mencapai Rp 17.111.0007 dan pada akhir tahun 2017 mencapai Rp 30.920.000. ${ }^{14}$

Berdasarkan hasil wawancara tersebut, sejalan dengan tujuan pembangunan nasional Indonesia untuk mencapai terciptanya masyarakat adil dan makmur berdasarkan demokrasi ekonomi, dikembangkan sistem ekonomi yang berlandaskan pada nilai keadilan, kebersamaan, pemerataan, dan kemanfaatan yang sesuai dengan prinsip syariah, nilai keadilan dalam kegiatan usaha perbankan syariah adalah tergambar dari beragamnya akad yang dipergunakan sebagai upaya penyesuaian berdasarkan kebutuhan secara proporsional, yang dilakukan oleh Bank BPRS Bahari Berkesan Kota Ternate

Dana dana sosial dari agniya dikelola oleh BPRS Bahari Berkesan dalam tiga kategori. Pertama, dana tersebut langsung disalurkan kepada orang-orang yang berhak menerima zakat, yaitu para fakir miskin yang kesulitan untuk memenuhi kebutuhan konsumsi sehari hari. Kedua, dana sosial tersebut dikelola dalam bentuk

${ }^{14}$ Alwi Albaar, Komisaris Bank BPRS Bahari Berkesan, Wawancara, Ternate tanggal 20 Agustus 2018. 
pembiayaan LKM bagi orang orang miskin yang masih bisa bekerja. Dengan demikian ada upaya starting point pemberdayaan. Jika penerima LKM tersebut telah bisa mengembalikan pembiayaannya, maka jenis pembiayaan yang diberikan ditingkatkan menjadi pembiayaan soft loan, dimana bagi hasil untuk BPRS Bahari Berkesan relatif kecil. Jika kondisi nasabah tersebut telah bergeser ke arah keberdayaan maka diberlakukan pembiayaan secara normal. Ketiga, dana sosial tersebut diberikan dalam bentuk soft loan kepada orang miskin yang masih sanggup bekerja dan relatif masih bisa memenuhi kebutuhan keluarganya. Sambil mendapatkan pembiayaan, mereka dimotivasi untuk menabung agar memiliki modal mandiri.

Berdasarkan wawancara terhadap nasabah yang juga sebagai salah satu pedagang pasar Barito kota Ternate yaitu Ibu Halimah pada saat diwawancara ibu menyampaikan sebagai berikut:

Pembiayaan yang dilakukan oleh BPRS Bahari Berkesan dengan produk PISANG selama ini sebagian telah tepat sasaran, contoh seprti saya dan temanteman lainnya, sebelum kami melakukan peminjman kepada koperasi untuk bangun modal berjualan di pasar ini, memang kami sangat terbantukan pada sisi kebutuhan sehari-hari, akan tetapi pada sisi yang lain kami tidak bisa menabung, karena disetiap hari kami ditagih oleh pihak koperasi, sedangkan dagangan kami tidak selamanya laris setiap hari, jadi kami harus persiapkan uang cadangan untuk disetor setiap hari dan kami rasa kewalahan bisa kami bertahan selain kami memiliki modal cukup besar. Ketika kami mengetahui dari sosialiasi yang dilakukan oleh Bank BPRS Bahari Berksesan dengan Produk yang ditawarkan serta menggunakan akad mudharabah, Alhamdulillah sampai sekarang kami masih terbantukan, karena uang kami langsung tersimpan di Bank untuk menjadi kebutihan kami yang berjangka panjang, selain kebutuhan sehari-hari kemai terpenuhi, simpanan kami juga ada di Bank. ${ }^{15}$

Berdasarkan hasil wawancara dalam teori hukum ekonomi syariah bahwa tolong menolong adalah pertukaran manfaat mengandung pengertian keterlibatan orang banyak, baik secara individu maupun lembaga. Oleh karena itu dalam pertukaran manfaat terkandung norma kerja sama (musyarakah). Pertukaran manfaat juga terkait hak milik seseorang karena perputaran manfaat hanya dapat

${ }^{15}$ Halimah, Pedagang pasar Barito Kota Ternate, Wawancara, Ternate 16 September 2018. 
terjadi dalam benda yang dimiliki. Proses pertukaran manfaat melalui norma kerja sama (musyarakah) dan norma hak milik berakhir dinorma tolong menolong (alta'awun). Dalam Islam, tolong menolong hanya terjadi dalam kebaikan dan ketaqwaan serta dalam hal yang membawa manfaat bagi semua. ${ }^{16}$

Dari wawancara yang disampaikan oleh ibu Halimah terkait produk pembiayaan PISANG Pinjam Sambil Simpan, dapat meningkatkan ekonomi kami. Selanjutnya pada kesempatan yang sama juga kami mewawancara kepada nasabah yang membuka usaha pedagang penjualan daging sapi, oleh bapak Ibrahim dalam penyampaian singkatnya yaitu:

Saya menilai pembiayaan yang dilakukan oleh BPRS Bahari Berkesan Kota Ternate dengan menggunakan produk pisang telah tepat sasaran karena yang diberi pembiayaan adalah mereka yang sangat membutuhkan. Tapi kalau soal pemberdayaannya, belum jelas. mas, soalnya pendekatan bisnis yang dilakukan oleh BPRS lebih kepada mencari laba. ${ }^{17}$

Dari penyampaian bapak Ibrahim dan ibu Lastri yang juga sebagai nasabah dengan usaha penjualan tomat dan rica serta sayur di pasar Higenis Kota Ternate, pada saat wawancara mengatakan sebagai berikut:

Pemberian modal dengan produk PISANG Pinjam Sambil Simpang Uang, dalam bentuk Pembiayaan yang dilakukan BPRS dengan menggunakan akad Mudharabah, atau berdasarkan ekonomi Islam, kami bersama teman-temang yang diberikan modal oleh bank sudah tepat sasaran karena yang dibidik masyarakat miskin. ${ }^{18}$

Pernyataan yang sama juga disampaikan oleh nasabah bernama Isra sebagai pedagang penjualan Ikan di Pasar Higenis Kota Teranate, pada saat diwawancara di mengatakan mengatakan sebagai berikut:

Pembiayaan yang dilakukan BPRS Bahari Berkesan sudah tepat sasaran karena diberikan kepada yang membutuhkan, karena pembiayaan sangat

16 Atang Abd Hakim, Fiqh Perbankan Syariah Transformasi Fiqih Muamalah Ke Dalam Peraturan Perundang-Undangan, 1, 2011.

17 Ibrahim, Pedagang Penjual Daging Sapi di Pasar Barito Kota Ternate, Wawancara, Ternate tanggal 17 September 2018

18Ibu Lastri Nasabah Penjualan Tomat Dan Rica Serta Sayur Di Pasar Higenis Kota Ternate, Wawancara, Ternate 20 September, 2018 
membantu kepada kami dalam mengembangkan ekonomi, untuk mewujudkan kebutuhan kami sehari-hari19

Selain penyampaian dari bapak Isra selaku pedagang penjualan ikan, bapak Zulkifli yang berprofersi sebagai pedagang ikan di pasar Higenis Kota Ternate, mengatakan yaitu:

Zulkifli menilai bahwa pembiayaan yang diberikan oleh Bank BPRS Bahari Berkesan Kota Ternate, dengan produk Pinjam Sambil Simpan Uang, selama ini sudah tepat sasaran. dan saya mengetahui, pembiayaan di BPRS Bahari Berkesan itu sudah yang punya bisnis dan punya agunan. ${ }^{20}$

Sebagian nasabah yang menilai bahwa pembiayaan BPRS telah tepat sasaran ada yang mendasarkan pada keberpihakan terhadap rakyat miskin seperti yang disampaikan oleh Ibrahim dan Lastri bahwa pembiayaan BPRS lebih ditujukan kepada masyarakat miskin dan membutuhkan. Pernyataan kedua responden ini tentu didasarkan pada pengetahuan sekilas mereka tentang pemberdayaan, namun setidaknya persepsi nasabah telah menunjukkan bahwa pembiayaan juga melibatkan masyarakat miskin. Dari pelaksanaan produk Pinjam Sambil Simpan Uang, mempunyai sasaran tersendiri, dalam keterangan yang diberikan oleh bapak Alwi Albaar ketika diwawancarinya yaitu:

Hal ini merupakan tinjauan dari satu sudut pandang tertentu yang tidak bisa diabaikan, Artinya, terlepas dari pembiayaan dengan jenis tertentu, maka fokus pembiayaan terhadap masyarakat miskin dan yang membutuhkan itu masih ada. Tentu saja model pembiayaan kepada masyarakat miskin seperti ini seharusnya menggunakan aqad qard al hasan. ${ }^{21}$

Dari hasil wawancara beberapa responden telah menunjukkan bahwa pembiayaan BPRS sudah tepat sasaran didasarkan pada pendekatan bisnis. Artinya, pembiayaan diberikan kepada pebisnis yang punya agunan. Model pembiayaan seperti ini dilakukan dalam skema musyarakah atau bahkan skema mudharabah. Para pebisnis desa yang mendapat pembiayaan dari BPRS pada kenyataannya juga

19 Isra, Sebagai Pedagan Penjualan Ikan di Pasar Higenis Kota Teranate, Wawancara, 16 September 2018) 2018

20 Zulkifli, Sebagai Pedagang Ikan Di Pasar Higenis Kota Ternate, Wawancara, 18 September ${ }^{21}$ Alwi Albaar, Komisaris Bank BPRS Bahari Berkesan, Wawancara, 20 Agustus 2018. 
bisa mengembangkan bisnisnya. Inilah yang kemudian menjadikan persepsi sebagian nasabah bahwa pembiayaan BPRS telah tepat sasaran karena diberikan kepada orang yang telah punya bisnis dan memiliki agunan. Sudut pandang pemberdayaan terhadap jenis pembiayaan seperti ini tentu harus dilihat dari sudut pandang pengembangan bisnis, dimana bisnis nasabah berkembang dan harus mampu menciptakan saving.

Sedangkan dari sisi kemanfaatan pembiayaan, sebagian nasabah berpendapat bahwa pembiayaan yang dilakukan oleh BPRS selama ini sudah bermanfaat kepada nasabah mengembangkan usaha mereka, seperti yang dirasakan oleh salah satu nasaba bapak Mahmud waktu diwawancara mengatakan sebagai berikut:

Nasabah BPRS Bahari Berkesan mengatakan, "Pembiayaan dari BPRS selama ini ya sudah ada manfaatnya, Pak. Manfaat yang paling besar saya rasakan selama ini adalah karena ada perhatian dari pihak BPRS Bahari Berkesan tentang perkembangan usaha saya, sehingga saya termotivasi untuk sukses dalam usaha ini. ${ }^{22}$

Demikian juga hal yang sama disampaikan oleh ibu Halimah saat diwawancara menyampaikan adalah sebagai berikut:

Saya sendiri mengakui ada manfaat dari pembiayaan di BPRS, minimal kita bisa membeli barang-barang dengan kredit dan tidak riba.", mengatakan, menurut saya manfaat yang didapatkan dari pembiayaan itu karena tidak riba dan lebih kecil bunganya dari rentenir serta persyaratannya lebih mudah. ${ }^{23}$

Pernyataan yang sama disampaikan nasabah dalam hal ini oleh bapak Zulkifli menyatakan yaitu:

Pembiayaan pembiayaan yang diberikan oleh BPRS ini sudah ada manfaatnya, terutama karena tidak riba mudah diakses dan tidak berbelit belit. ${ }^{24}$

22 Mahmud, Pedagang Sembako di Pasar Barito KotaTernate, Wawancara, Ternate 18 September, 2018.

${ }^{23}$ Halimah, Pedagang pasar Barito Kota Ternate, Wawancara, Ternate 16 September 2018.

24 Zulkifli, Pedagang Ikan di Pasar Higenis Kota Ternate, (Wawancara. Ternate, 18 September 2018. 
Selanjutnya bapak Isra pun menyatakan hal yang sama ketika peneliti melakukan wawancara kepada yang bersangkutan di lokasi penjualan pasar Higenis Kota Ternate yaitu:

Saya merasakan ada manfaat dari keberadaan pembiayaan BPRS karena bisa mengurangi rentenir. Selain itu usaha bebek petelur yang saya kerjakan selama ini semakin berkembang, dan terutama para pedagang yang ada di pasar untuk mendapatkan pinjaman." 25

Pernyataan beberapa nasabah yang menganggap bahwa pembiayaan yang dilakukan oleh BPRS Bahari Berkesan telah membawa manfaat rata-rata karena mereka menilai bahwa bisnis mereka menjadi lebih berkembang setelah adanya pembiayaan. Selain itu mereka menganggap bahwa akses untuk mendapatkan modal lebih mudah dan tidak berbelit-belit, Sedangkan yang lainnya beranggapan bahwa pembiayaan di BPRS Bahari Berkesan itu mudah dan tidak riba. Jadi faktor sprin'tual masyarakat rupanya menjadi penimbangan untuk memberikan pembiayaan kepada nasabah. Selain itu sebaiknya pembiayaan diberikan dengan mekanisme yang lebih simple dan tidak berbelit-belit karena hal itu akan memudahkan nasabah. Yang paling penting adalah harus ada upaya pemberdayaan agar bisnis atau usaha nasabah menjadi berkembang setelah adanya pembiayaan. Jika hal tersebut dilakukan oleh BPRS, maka nasabah akan menganggap bahwa pembiayaan yang dilakukan oleh BPRS selama ini ada manfaatnya.

Pembiayaan BPRS Bahari Berkesan meliputi pembiayaan produktif, investasi konsumtif, dan jasa. Pembiayaan produktif yang dijalankan oleh BPRS Bahari Berkesan ditujukan untuk membiayai usaha-usaha baru maupun membiayai usaha yang telah berjalan yang diajukan oleh nasabah Jika yang dibiayai adalah usaha ham, maka akad yang digunakan adalah akad mudarabab. Jika yang dibiayai adalah bisnis yang telah berjalan namun membutuhkan pengembangan usaha, maka akad yang digunakan adalah musharakall.

${ }^{25}$ Isra, Pedagang Penjualan Ikan di Pasar Higenis Kota Teranate, Wawancara, Ternate tanggal 16 September 2018. 
Baik akad mudharabah maupun akad musyarakah keduanya ditetapkan jangka waktunya yaitu interval satu hingga tiga tahun. Penetapan ini dimaksudkan untuk menjaga keamanan kerjasama serta mengukur tingkat keberhasilan pembiayaan yang sampaikan oleh Komisaris Bank BPRS Bahari Berkesan Bapak Alwi Albaar pada waktu di wawancara sebagai berikut:

Bapak Komisaris Bank BPRS Bahari Berkesan mengatakan bahwa pembiayaan produktif yang menggunakan akad mudarabah maupun akad musyarakah harus terkontrol sehingga waktunya maksimal tiga tahun. Dari situ bisa dianalisa hasil dari pembiayaan yang telah dilakukan. ${ }^{26}$

Bagi masyarakat atau nasabah yang menghendaki pembiayaan produktif ini harus memenuhi beberapa persyaratan yang ditetapkan oleh BPRS Bahari Berkesan, antara lain; a) mengisi formuulir perjanjian akad atau permohonan pembiayaan, b) melampirkan foto copy KTP/SIM/KK serta jaminan, c) menyertakan penjamin dan ahli waris pemohon, d) bersedia disurvey dan memberi info selengkapnya atau proposal kepada pihak BPRS.

Tatkala fungsi intermediasi ekonomi BPRS telah jalan, maka fungsi intermediasi sosial tidak dilupakan begitu saja. Fungsi intermediasi sosial BPRS bukan hanya fungsi pelengkap yang sifatnya pilihan (voluntary), tetapi menjadi fungsi utama pula berdasarkan tujuan pendirian BPRS.

Berdasarkan Visi dan misi didirikannya BPRS Bahari Berkesan, maka intermediasi sosial merupakan peran utama pula yang harus dijalankan oleh BPRS Bahari Berkesan. BPRS Bahari Berkesan berusaha secara optimal menerima dana sosial berupa zakat, infak, sedekah, hibah, wakaf dan dana sosial lainnya dan menyalurkannya kepada masyarakat yang membutuhkan. Oleh karena itu BPRS Bahari Berkesan juga mengoptimalkan qard al hasan dalam beberapa pembiayaan. Fungsi tersebut menjadi karakteristik utama BPRS Bahari Berkesan dan menjadi daya tarik positif dalam melayani kebutuhan jasa keuangan masyarakat. Fungsi ini menyempurnakan BPRS Bahari Berkesan yang bukan hanya sekedar menjadi lembaga intermediasi pembiayaan ke sektor usaha tetapi juga berperan membantu

${ }^{26}$ Alwi Albaar, Komisaris Bank BPRS Bahari Berkesan, Wawancara, Ternate 20 Agustus 2018. 
memperlancar upaya peningkatan kesejahteraan masyarakat khususnya masyarakat golongan bawah.

Kegiatan saling tolong menolong dalam pembiayaan yang dilakukan oleh BPRS sebagai lembaga intermediasi merupakan pengejawantahan dari ayat AlQur'an karena dalam pembiayaan tersebut masing-masing pihak merasa mendapatkan keuntungan dari kerjasama yang dilakukannya. Kegiatan tolong menolong ini tidak dilakukan secara sesaat, namun berkelanjutan karena esensi pemberdayaan adalah bersifat keberlanjutan. Dengan demikian, kegiatan intermediasi BPRS yang menekankan pada pembinaan kepada nasabah juga mampu menciptakan suasana nyaman kepada pihak pihak yang terkait dengan BPRS. Dalam konteks nilai ke Islaman, terdapat ayat al Qur'an yang menjelaskan hal tersebut, yaitu pada Qur'an surah al Anfal, 8:63. Sekalipun ayat tersebut membahas tentang bersatunya kaum Aus dan Khaz raj, suasana nyaman yang diciptakan oleh Nabi tersebut dapat pula dianalogikan kepada suasana nyaman yang terjadi diantara nasabah BPRS yang diciptakan oleh fungsi intermediasi BPRS yang membangun potensi ekonomi masyarakat, melakukan pembinaan nasabah dan fungsi fungsi intermediasi lainnya. Upaya upaya ini menjadikan stakeholders BPRS dapat bekerja dalam suasana saling percaya dan saling menguatkan.

\section{Mewujudkan Kesejahteraan Ekonomi Ummat di Kota Ternate}

Seiring dengan semangat ummat Islam untuk berusaha menerapkan ajaran agamanya, muncullah kajian tentang kesejahteraan dalam perekonomian yang berbasiskan syariah Islam. Paradigma ini menjelaskan bahwa kesejahteraan masyarakat akan dapat tercapai bila seluruh aktivitas manusia berlandaskan syariah atau hukum-hukum Islam.

Kesejahteraan, kemakmuran, dan kebahagiaan telah dijamin oleh Tuhan. Memang sumber-sumber daya yang disediakan Tuhan di dunia ini tidak terbatas, namun semua itu akan dapat mencukupi bagi kebahagiaan manusia seluruhnya jika dipergunakan secara efisien dan adil. Manusia dapat melakukan pilihan terhadap berbagai kegunaan alternatif dari sumber-sumber tersebut. Namun harus disadari 
bahwa jumlah ummat manusia bukanlah sedikit tetapi dalam jumlah yang besar. Oleh karenanya, penggunaan sumber-sumber tersebut hanya bisa dilakukan dengan perasaan tanggung jawab dan dalam batasan yang ditentukan oleh petunjuk Tuhan dan maqasidnya.

Secara filosofis, perbankan syariah merupakan lembaga keuangan yang sesuai dengan ideologi bangsa Indonesia yaitu Pancasila dan pembukaan Undang-Undang Dasar 1945. Pancasila yang memberikan landasan nilai-nilai mulai dari sila pertama "Ketuhanan Yang Maha Esa, hingga sila kelima "Keadilan Sosial Bagi Seluruh Rakyat Indonesia" kelima sila itu tidak ada satupun yang bertentangan dengan perbankan syariah yang menerapkan prinsip syariah berbagi keuntungan dan kerugian. Begitu pula Bank Syariah sudah sesuai dengan pembukaan Undangundang Dasar 1945 yang menggariskan suatu cita-cita sebagai negara Indonesia yang adil dan makmur, yang juga merupakan salah satu tujuan sistem hukum perbankan syariah di Indonesia. ${ }^{27}$

Pertumbuhan ekonomi masyarakat kota Ternate sebagai peningkatan dalam kapasitas suatu bangsa jangka panjang untuk memproduksi barang dan jasa bagi rakyatnya. Sementara pertumbuhan ekonomi menurut Islam adalah sebuah pertumbuhan produksi atau hasil yang terus menerus dengan cara yang benar dan dapat memberikan kontribusi bagi kesejahteraan ummat manusia.

\section{E. Penutup}

Penerapan Akad pada Produk Pinjam Sambil Simpan Uang (PISANG) yang menggunakan akad mudharabah dalam pelaksanaanya mempunyai karakteristik yaitu pembiayaan yang menggunakan akad mudharabah telah sesuai dengan pedoman pelaksanaan pembiayaan mudharabah yang ditetapkan oleh OJK dan BI. Selain itu, Pembiayaan Pisang telah sesuai dengan fatwa DSN MUI tentang Mudharabah dalam perbankan syariah dan sesuai dengan SOP yang ditetapkan

27 Mustaghfirin, Rekonstruksi Sistem Hukum Perbankan di Indonesia Kajian dari Aspek Filososfis, Sosiologis dan Budaya, Unissula Press, Semarang, 2006, h. 9-16. Dan Dadan Muttaqien, Sistem Perbankan Syariah di Indonesia dalam Perspektif Politik Hukum, Disertasi Universitas Diponegoro, Semarang, 2007), h.361. 
oleh BPRS dan DPS BPRS Bahari Berkesan. Adapun Tahapan Pembiayaan Pisang menerapkan prinsip kehati-hatian dan manajemen risiko.

Peran Produk Pinjam Sambil Simpan Uang terhadap pemberdayaan telah berupaya peningkatan ekonomi ummat kota Ternate dalam melakukan pemberdayaan ekonomi masyarakat yang melibatkan tiga unsur utama pemberdayaan, yaitu strategi pemberdayaan, teknik pemberdayaan dan pengkondisian pemberdayaan. Ketiga unsur pemberdayaan tersebut diimplementasikan dengan aktifitas riil berupa segmentasi nasabah yang telah berdaya dan yang belum berdaya, treatment pembiayaan berjenjang, pembinaan intensif, penyediaan sumber daya insani yang memahami visi dan misi pemberdayaan, optimalisasi fungsi intermediasi ekonomi dan intermediasi sosial, serta motivasi dan penyediaan sarana menabung terkoordinir. Pemberdayaan dilakukan dengan menekankan pada keberpihakan terhadap masyarakat bawah dan kelompok terpinggirkan serta menjalin kerjasama dengan lembaga-lembaga terkait serta memobilisasi dan optimalisasi penggunaan sumber daya secara keberlanjutan.

Akhirnya, Fungsi BPRS bukan sekedar sebagai mitra atau lembaga intermediasi saja, namun lebih dekat pada fungsi coaching terhadap nasabah. Selain sebagai coaching, BPRS juga menekankan pada pembiayaan jenis bagi hasil untuk mengimbangi banyaknya pembiayaan dengan pola jual beli atau murabahah. Hal itu berarti BPRS lebih mengedepankan balancing dalam bisnis, baik balancing dalam hal pembiayaan maupun balancing dalam hal model bisnis.

\section{DAFTAR PUSTAKA}

Antonio, Muhammad Syafi'i. Bank Syriah Wacana Ulama Dan Cendekiawan. Jakarta: Tazkia Institute, 2002.

Ascaraya. Akad Dan Produk Bank Syariah. Jakarta: Raja Grafindo Persada, 2008.

Hakim, Atang Abd. Figh Perbankan Syariah Transformasi Fiqih Muamalah Ke Dalam Peraturan Perundang-Undangan. 1, 2011.

Muhammad. Konstruksi Mudharabah Dalam Bisnis Syari'ah. Yogyakarta: BPFE, 2005. 
Nainggolan, Dr. Basaria. Perbankan Syariah Di Indonesia. Depok: PT Rajagrafindo Persada, 2016.

Rita Yasin, Wawancara, 13 Pebruari 2018

Alwi Albaar, Wawancara, 20 Agustus 2018.

Halimah, Wawancara, 16 September 2018.

Ibrahim, Wawancara, 17 September 2018.

Zulkifli, Wawancara, 18 September 2018.

Mahmud, Wawancara, 18 September 2018.

Isra, Wawancara, 16 September 2018. 